\title{
10. Slovenia: Is the weakening of industrial relations taking its toll on social convergence?
}

\section{Branko Bembič}

\section{INTRODUCTION}

Embarking on the transition from socialism to capitalism in the early 1990s, various paths to capitalism as well as distinctively different 'final destinations' were open to the societies of central and eastern Europe. ${ }^{1}$ Most commonly, the developed capitalist societies are grouped in one of two ideal-types of institutional model: liberal market economies, which rely mainly on market coordination, and coordinated market economies, in which non-market coordination plays an important role (Hall and Soskice 2001). Nevertheless, most of the eight acceding central and eastern European (CEE) countries followed a path towards a (neo)liberal regime and adopted a dependent market economy model, characterised by specific institutions and comparative advantages built around these economies' (subordinated) role in the hierarchy of international corporations (Nölke and Vliegenthart 2009). Dependent market economies are characterised by their dependence on foreign direct investment (FDI) for raising investment and their most important companies are hierarchically controlled by the headquarters of foreign multinationals. This puts the latter in a perfect position to erode the inclusiveness of industrial relations institutions and instead rely on selective company-level agreements. Vocational education survives, but heavy competition for FDI using tax breaks and low labour costs does not allow for a generous public education system. With technology transfer from multinationals, there is no need for investment in innovation-relevant skills, nor for mechanisms enabling extensive non-market inter-company relations. In enabling multinational companies to smoothly adjust employment to the desired level, labour markets are more flexible than in coordinated market economies but less flexible than in liberal market economies in order to restrict the fluidity of their skilled work force. Finally, the favourable tax treatment and incentives offered to foreign investors might undermine the state's capacities to sustain welfare provisions. The institutional arrangements described are supposed to support comparative advantages in the assembly of complex consumer and durable goods based on skilled, but cheap, labour (Nölke and Vliegenthart 2009).

In contrast to most CEE post-socialist countries, Slovenia constructed a distinctive institutional architecture with several features of coordinated market economies and strong corporatist features (Buchen 2007; Feldmann 2007), which eased dependence on FDI and allowed for a socially more balanced transition. This chapter examines the most important contributions of industrial relations to the process of institution-building 
and thus social convergence. The main line of argument is that there has been a close relationship between economic and social convergence in Slovenia, especially during the early periods of transition when, in the process of social dialogue, measures with a strong impact on economic convergence were exchanged for reforms leading to upward convergence in social standards. With the changing environment, social dialogue deteriorated and subsequently collapsed, and social convergence stalled. Nevertheless, social dialogue at both national and sectoral levels was resuscitated after 2013, which indicates its economic functionality, as well as opportunities for social convergence.

Section 2 provides an overview of Slovene industrial relations developments in view of their impact on the social convergence process. The contribution of industrial relations to social convergence in selected areas is analysed in section 3, which is followed by a case study on the international cooperation of Slovene trade unions in response to transnational corporate activities (section 4). Section 5 concludes.

\section{INDUSTRIAL RELATIONS AND SOCIAL DIALOGUE AS A LINK BETWEEN ECONOMIC AND SOCIAL CONVERGENCE IN SLOVENIA}

\subsection{Formation of Industrial Relations Actors and Establishing Preconditions for Social Dialogue (1987-92)}

Two social forces that decisively shaped the Slovene transition path emerged and were consolidated in the 1987-92 period. The first was the discontented working class that saw a progressive deterioration in material conditions during the transformational depression. Its dissatisfaction was articulated by the trade union movement, which defeated the government over its attempted imposition of the wage freeze in the 1992 general warning strike. The strike was a turning point that established the trade unions as a partner that every subsequent government had to reckon with (Crowley and Stanojević 2011). Owing to the strength of organised labour during the transition period, Ost's (2000) claim about 'illusory corporatism' in CEE countries is not persuasive in the case of Slovenia. The other important force in the Slovene transition was the emerging domestic business class. It was composed of highly influential managements of once self-managed companies that de facto controlled the companies, even during the socialist era (cf. Županov 1985; Djokić 2015) and nurtured aspirations to assume the position of a domestic capitalist class in the emerging capitalism.

Both groups demanded to be included in the privatisation of 'their companies' at an early stage of transition (Simoneti et al. 2003; Vrhovec 2010; Feldmann 2014, pp. 78-9). An important (proto-)agreement between the two social forces was struck with the Law on Privatisation (the Official Gazette of the Government of Slovenia - UL RS 55/1992), which favoured insider owners to the almost total exclusion of foreign bidders (Mencinger 2006). Some of the cornerstones of Slovene industrial relations were put in place during this early period. For instance, the first general collective agreement for the private sector was signed and followed by industry-level collective agreements, and tripartism was established in the social insurance system. 


\subsection{Impact of Industrial Relations on Economic and Social Convergence (1987-92)}

The general strike that abolished the wage freeze was important for economic convergence because it strengthened internal demand and helped to pull the economy out of recession (Bole 1997), while at the same time preserving workers' purchasing power. With regard to economic convergence, the Law on Privatisation enabled the transformation of social property into private (and state) property, which was essential for the transition to a capitalist economy. From the perspective of social convergence, insider ownership attenuated the socially disruptive effects of this transition and ensured socially more sustainable outcomes. First, companies with workers' ownership and board representation, on average, undertook less aggressive downsizing, had less precarious employment arrangements and used less overtime, but also faced fewer strikes (Prašnikar et al. 2000). Secondly, insider privatisation helped to avoid dependence on FDI, which later enabled the country to be less burdened by the imperative to please international investors by lowering social standards. Tripartism in the system of social insurance was important for the preservation of the welfare state (for example, universal public health-care provision).

\subsection{Striving for Real Convergence through Social Dialogue (1992-2001)}

After Slovenia left the Yugoslavian federation and lost access to its market, two items came to the top of the list of economic priorities: taming the very high rate of inflation and ensuring the external liquidity of a suddenly highly open Slovene economy. At the outset of the transition the task was almost entirely left to macroeconomic policy (exchange rate policy, monetary and fiscal policy). The entering into force of collective agreements with strong wage increases in the public sector, which were spilling over to the business sector, the defeat of the government's wage freeze in 1992 and the continuing increase in government controlled prices pushed up prices in the domestic market-orientated sectors. This, in turn, put pressure on wages and costs in the export sector, threatening its competitiveness (Bole 1997; 2002). Furthermore, in the absence of external financing by FDI and with monetary authorities preventing credit inflows to Slovene banks from abroad in order to keep control over the money supply (Mrak 2010), aggregate domestic savings had to be increased to allow for a higher investment rate (UMAR 1997, p. 8; Kajzer et al. 2007). These problems in the economic sphere made some kind of agreement on income policies highly desirable, while a strong union confederation in the private sector and a centralised employers' organisation - both capable of influencing their respective members - made such an agreement feasible.

The first Agreement on Incomes Policy (UL RS 23/1994) was finally signed in 1994 (Kavčič 2004). ${ }^{2}$ It specified a very restrictive incomes policy that tied the rate of wage growth slightly below the rate of inflation, with no provisions for increases owing to productivity growth. The main concession to organised labour was the establishment of a tripartite Economic and Social Council (ESC). Similar agreements followed throughout the period under examination (Stanojević and Krašovec 2011). Many incomes policy agreements were accompanied by social agreements that provided institutional elements conducive to social and economic convergence (UL RS 23/1994, UL RS 22/1995, UL RS 29/1996, 22/1999). For instance, in order to improve firms' cost competitiveness, a reduction in the employers' part of pension contributions was agreed, while a progressive 
payroll tax was introduced. The agreements included several elements of solidaristic policy: the introduction of the minimum wage in 1995, which in later pacts was set to grow higher than other wages; a progressive determination of holiday pay; reduced income tax for those at the bottom of the income distribution; extra wage allowances for low-wage earners to compensate for price increases following tax changes; and a provision for conversion of successive fixed-term contracts of employment into open-ended contracts (which was only realised after some years).

Several issues were resolved outside the social pacts. The Law on Worker Participation in Management that ensured codetermination rights was passed in 1993 (UL RS 42/1993). In 1995 the social partners agreed on the establishment of the solidarity fund, which covers the wages and severance pay of bankrupt companies (UL RS 25/1997). Important laws and reforms, such as the Law on Employment Relationships and Unemployment Insurance, which retained relatively high unemployment replacement ratios (UL RS 69/1998), and the Law on Occupational Safety and Health (UL RS 56/1999) were discussed - although agreement was not always reached on all details - in the ESC. The protracted process of adopting the pension reform (UL RS 106/1999), in which large demonstrations organised by the trade unions were followed by intense social dialogue, was completed in this period. The trade unions successfully prevented the introduction of a fully funded second pillar and the equalisation of retirement conditions for men and women, and managed to reduce the ratio between the highest and lowest pensions. Another systemic law, the Law on Employment Relationships (UL RS 42/2002) was negotiated in the ESC by the end of 2001. The law sought to comprehensively regulate employment contracts and incorporated many of the areas previously determined in collective agreements (Šenčur Peček 2003); it also provided for several measures in the area of gender equality (Robnik 2016).

\subsection{Impact of Industrial Relations on Economic and Social Convergence (1992-2001)}

As we have already indicated, restrictive incomes policies were essential for economic convergence in Slovenia. First, slower wage growth contributed to lower inflation, with no need to resort to 'shock therapy'. Secondly, incomes policies helped to ease wage growth pressure in the sectors selling on the domestic market - which was spilling over to the export sector - and thus helped to preserve its export competitiveness. Thirdly, the lagging of wages behind productivity growth increased corporate profits, which in turn enabled companies to finance the new investment needed for restructuring. This was important because in the second half of the 1990s the high supply of securities on domestic capital market (workers were selling the shares acquired in the privatisation process) limited the opportunities for issuing new shares (Mramor and Jašovič 2004, pp. 280-81), while interest rates on bank loans were kept high, which meant that companies' investment had to rely on internally generated funds (Domadenik et al. 2000, 2003). That is, while most CEE economies became dependent on FDI during the 1990s, internal financing in part enabled by incomes policy provided a source of 'patient capital' for economic development and convergence. Very restrictive incomes policies are probably the main cause of a sharp decrease in wage share during the second half of the 1990s (Figure 10.1). That is, the price for the gains that organised labour managed to achieve in the area of social convergence was to delay a faster wage convergence. 


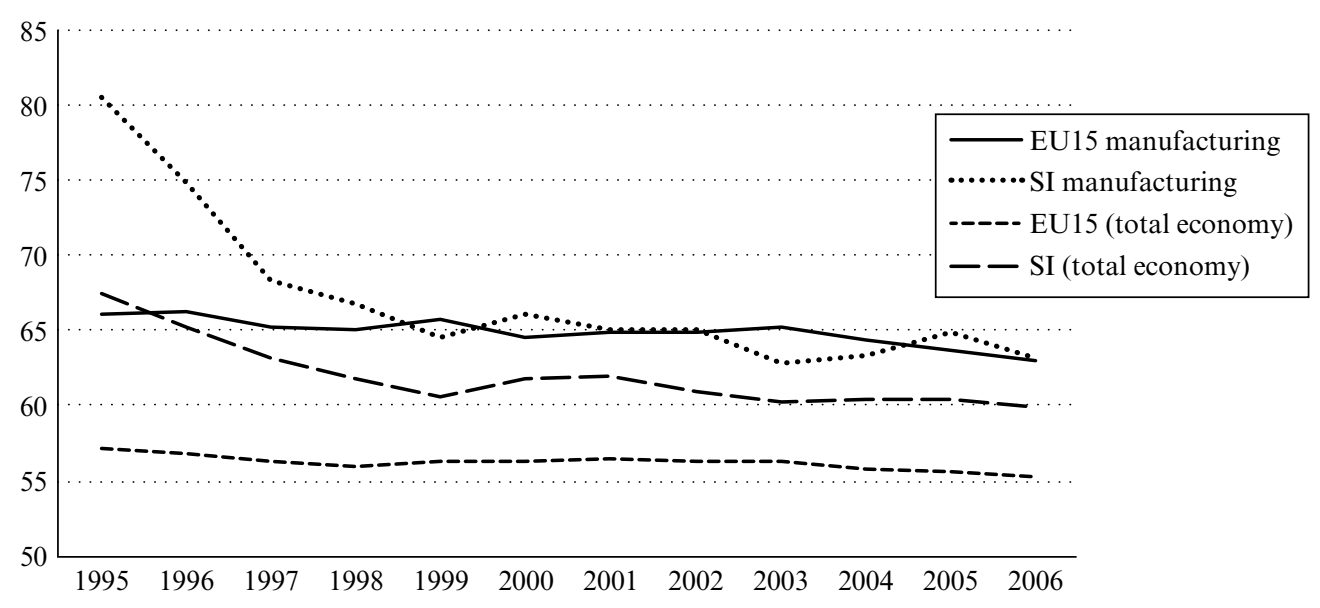

Figure 10.1 Wage shares: total economy and manufacturing, Slovenia and EU15, 1995-2006

Restructuring was further facilitated by shop-floor trade union representatives, who provided management with an interlocutor and served as mobilisers of survival coalitions (Stanojević 2004), in which stability of employment and secure wages were exchanged for increasing intensification of work. Pension reform helped economic convergence by preserving the pension system's sustainability. Finally, a relatively high replacement rate for unemployment benefits, coupled with fairly strong employment protection stimulated investment in industry- and firm-specific skills.

Restrictive incomes policies were exchanged for policy elements that underpinned social convergence. Institutionalisation of the peak-level tripartite institution, the ESC, provided an institutional infrastructure for future negotiations on matters of both economic and social convergence. Introduction of the minimum wage and provisions to enable it to grow more than other wages ensured a certain wage compression and held income inequalities in check. Income tax cuts for the lowest income bracket further reduced income inequalities and improved the lot of the most vulnerable. By preserving the first pillar and reducing the ratio between high and low pensions the pension reform prevented an increase in inequality among pensioners, while more favourable retirement conditions for women served as financial compensation for the unpaid work they render. A high unemployment replacement ratio and the solidarity fund both provided some income security for the unemployed. Coupled with employment protection that the new Law on Employment Relationships retained at a level comparable to coordinated market economies such as Germany and Austria and thus favoured long-term relations between firms and employees, this further encouraged investment in industry-specific skills. Chaining of successive fixed-term contracts was limited to two years. The Law on Employment Relationships improved income security by mandating various allowances - for example, for meals at work - and strengthened upward social convergence with regard to gender equalities as it prohibited asking job candidates questions related to family and marital status, pregnancy and family planning; called explicitly for equal pay for equal work; and instituted several measures on 
the reconciliation of work and family life, as well as protection in case of pregnancy and parenthood (Robnik 2016).

In summary, during the 1990s, social dialogue and industrial relations provided several building blocks for an emerging coordinated market economy. Patient capital was provided by insider ownership and internal financing, which favoured a long-term orientation on the part of management. This in turn created a favourable environment for investment in specific skills, while the welfare state provisions and labour legislation further encouraged both firms and workers to nurture long-term relations. The role of social dialogue in macroeconomic stabilisation (inflation) and the competitiveness of the export sector reduced the need for 'shock therapy' and, finally, reduced social inequalities.

\subsection{Social Dialogue in the Years of Nominal Convergence (2001-04)}

In the early 2000 s the main institutions were in place and the phase of preparation for a 'soft landing' in the European Union (EU) and European Exchange Rate Mechanism 2 (ERM2) began. The policy priorities shifted to compliance with the Maastricht criteria of nominal convergence. As part of the EU accession commitments, capital flows were liberalised, which made control of domestic demand by means of macroeconomic policy much more difficult. Also, the fiscal stance deteriorated gradually in the second half of the 1990s, while at the same time accession commitments brought further pressures (Bole and Mramor 2006). At that point, a fiscal policy combined with an incomes policy was badly needed that could support the government's macroeconomic policy and bring the deficit in line with the Maastricht criteria.

The unions consented and another round of incomes policy agreements followed in the private sector (UL RS 52/2002; 73/2003), which entailed a new mechanism of adjustment of starting wages set in collective agreements, but also a provision stipulating faster growth of the minimum wage than starting wages. Importantly, the government and the public sector trade unions also agreed to divert a part of public workers' wage increases into a special second pillar of the pension insurance scheme. A new and very extensive Social Pact (UL RS 40/2003) followed in 2003. In addition to the commitments to fulfilment of the Maastricht criteria on inflation, the pact laid down the basic contours for several reforms. An income tax reform, among others, provided some relief to those at the bottom of the income distribution. Changes in corporate tax and some other taxes were also scheduled. The document contained an ambitious chapter on vocational education and training, and a progressive reform of health care insurance, including the abolition of the (regressive) supplementary insurance. Several new topics emerged, including work-life balance.

\subsection{Impact of Industrial Relations on Economic and Social Convergence (2001-04)}

From the standpoint of economic convergence, the incomes policy agreements and the agreement with the trade unions in the public sector were - in combination with standard macroeconomic policies - essential for the nominal convergence (fulfilling the Maastricht criteria) needed for a quick and smooth landing in the ERM2 and later in the euro zone, which Slovenia entered in 2007. Provisions on the minimum wage and income tax helped social convergence by maintaining a low level of income inequalities. However, many of 
the progressive measures promised in the social pacts that would stimulate social convergence - most notably reform of health insurance - were never realised.

\subsection{Weakening the Social Dialogue and Build-up to the Crisis (2004-08)}

After the country joined the EU, the environment in which the actors operated changed substantially, and this affected the social dialogue. The process of accession to, and full membership of, the EU and euro zone brought differentiated results for various social classes. Business clearly benefited by being able to tap the resources of the vast financial market (Deželan and Košak 2006), while the core export industries - such as the chemical, metal and electric industries - gained unrestricted access to the EU single market (Lavrač and Majcen 2006). However, the declining 'sunset' sectors, such as the apparel, textiles or wood industries, laid off their employees, who sometimes ended up in poorly paid jobs requiring lower and more general skills in the expanding traditional service sectors, such as retail or hospitality. These sectors were disproportionally affected by gradual labour market flexibilisation and feature higher than average shares of various forms of non-standard (mainly precarious) employment. Wages and working conditions in the thriving export sector, demanding industry-specific skills, were gradually improving. A process of labour market segmentation not dissimilar to tendencies found in some of the core EU countries could be observed during this period (Palier and Thelen 2010; Thelen 2012; Hassel 2014).

Diverging business conditions across private sector industries put an increasing strain on the centralisation and thus inclusiveness of collective bargaining. A closer integration into European financial markets, convergence of interest rates to euro-zone levels and an ample supply of credit from abroad eased the dependence of companies' investment projects on internal funds. In sharp contrast to the 1990s, the investment boom in Slovenia after 2004 was financed by bank loans without heavy suppression of the wage share, which meant that the burning need for coordination diminished. Further, with inflation under control an important objective requiring intense coordination with organised labour was realised.

In the context of these developments industrial relations in Slovenia were gradually decentralised. From 1991 the public and private sectors had been covered by two general collective agreements, but in 2005 the employers' organisations cancelled the collective agreement for the private sector with the consent of the largest private-sector trade union confederation. Furthermore, membership of the main employers' association was changed from mandatory to voluntary in 2006. This period also saw an abrupt fall in the union density rate.

The quality of social dialogue deteriorated significantly in 2005 when the new centreright government tried unilaterally to adopt a package of neoliberal reforms. The most contentious was the proposal for a flat tax. More generally, the reform package aimed consistently at a thorough transformation of the existing institutional framework in the direction of a liberal market economy. The trade unions responded by mobilising public opposition, which culminated in large demonstrations in late 2005 (Stanojević 2015). The government subsequently abandoned the flat tax, although some parts of the package notably the activation-oriented reform of social assistance - were later adopted.

After 2006 the social dialogue became less strained as the Ministry of Finance 
withdrew the flat-tax proposal and some progress was achieved in certain areas. For example, the social partners negotiated changes in health insurance (UL RS 76/2008) in accordance with which, among other things, the state now covered supplementary health insurance for the socially vulnerable. The revision of the Law on Employment Relationships (UL RS 103/2007) in 2007 was also coordinated, which brought stronger legal protection and some other minor changes (Laporšek and Dolenc 2011). The Law on Social Assistance (UL RS 3/2007) of 2007, a type of leftover from the abandoned neoliberal reform package of 2005, was adopted with the ESC's approval. The law restricted the accessibility of cash benefits as it introduced a host of new conditions and reasons for excluding claimants from their entitlement to cash benefits, most of which was related to participation in the labour market (Leskošek and Dragoš 2015). A new and very extensive Social Pact for 2007-09 (UL RS 93/2007) was signed in 2007. Most of the 19 chapters were fairly general, but the pact also contained a government commitment to adopting important new legislation only with the agreement of the ESC. Also included was a chapter on activation-orientated social policy. Two measures aimed at halting the inflationary erosion of the lowest wages were coordinated consensually in the ESC in 2008 (UL RS 36/2008 and UL RS 78/2008).

\subsection{Impact of Industrial Relations on Economic and Social Convergence (2004-08)}

The period witnessed a booming economy, but economic convergence was based on shaky ground. In sharp contrast to the previous period, during 2004-08 a high level of investment activity was financed largely by inflows of cheap credit from abroad. The banks became heavily exposed to the risks associated with refinancing on foreign markets, while companies became strongly dependent on credit refinancing with domestic banks (Trobec 2012, pp.31-3). The increase in cross-border financial inflows that followed Slovenia's integration into the euro area relaxed the financing constraints for Slovene companies, raising hopes of faster upward economic convergence. These hopes were crushed after 2008 when refinancing of loans became increasingly difficult. As regards social convergence, the short 2004-08 period saw little advancement. The main accomplishment of industrial relations in this area was successful defence of social convergence achieved in previous periods against the government's attempt to impose a flat tax and other reforms that threatened to increase inequalities. Even the modest progress in equality, such as payment of health insurance to the most needy, was balanced by a regressive reform of social assistance that increased inequality.

The abandonment of agreements on incomes policies and social pacts, and gradual decentralisation of collective bargaining to sectoral level, further undermined the conditions for equality and social convergence as minimum conditions were no longer negotiated by strong confederations but by trade unions of unequal power and bargaining capacities. What is worse, this unwinding of industrial relations, coupled with a decrease in the trade union density rate, came at a time when the share of precarious employment arrangements grew precipitously (Bembič 2018, pp.427-8), which would require a unified response from the trade union movement. Instead, while the traditional service sectors, such as retail trade and tourism and hospitality, were heavily hit by the trend towards precarisation, the workers and their unions in these sectors enjoy a low level of structural power (Bembič and Butković, 2017) and were thus left with few resources to face the challenge. 
In summary, owing to trade union intervention, the main features of a coordinated market economy were largely preserved during 2004-08. Coordination of the economy was loosened up by abandoning social pacts and decentralising collective bargaining, which hardly benefited the economy. Social convergence stalled or even deteriorated in certain aspects, such as growing precarisation and sectoral divergence in wages and working conditions, as conditions for economic expansion were no longer mediated through social dialogue.

\subsection{The Collapse of Social Dialogue and Social Divergence in Crisis (2008-13)}

Social dialogue all but collapsed in 2008-13, which was certainly not a period of economic or social convergence. During the crisis the room for compromise was considerably narrowed, which led the government to bypass social dialogue and adopt decisions unilaterally (Stanojević and Kanjuo Mrčela 2016).

With the eruption of the crisis in late 2008, the risks associated with exposure to foreign financial markets that had accumulated during 2004-08 materialised. The government responded with anti-crisis measures. A short-time working scheme (UL RS 5/2009) and the institution of temporary layoffs (UL RS 42/2009) were approved in the tripartite ESC. Responding to workers' discontent, in 2009, the trade unions organised demonstrations and pressed for an increase in the minimum wage, which the government enacted in early 2010 without the consent of the employers, and the social dialogue became increasingly strained. The government then presented a package of neoliberal reforms in the ESC and unilaterally pushed it through the parliament. The Social Assistance Benefits Act (UL RS 61/2010), which gave the state the right to demand the repayment of cash assistance which could be recovered from inheritance in case the beneficiary dies (Leskošek 2012), proved immensely damaging. The pension reform with no provision of a lower retirement age for those who started work before the age of 18 and the introduction of the 'mini-jobs' that raised fears of conversions of regular employment into this much more flexible and informal arrangement met with a fierce response from the trade unions. They articulated popular discontent and both reforms were rejected in a wave of referendums, which also brought down the government.

Inadequate economic policy (including slow bank recapitalisation, ban on refinancing management buyouts and the harsh capital requirements on the part of the central bank enacted in 2010) deepened the crisis (Prašnikar et al. 2015, pp. 33-4) and the number of bankruptcies mounted. So did non-performing loans, and soon it became clear that the banks would need capital injections from the state (Senjur 2012, pp.3-5). At the same time the state was becoming increasingly indebted owing to a prolonged crisis. These developments coupled with a general deterioration on the European financial markets in autumn 2012 and several downgrades of Slovenia's sovereign debt - the rating agencies cited, among others, the rejection of the neoliberal reforms - led to a sharp increase in interest rates on government bonds and a liquidity crisis of the public finances ensued.

The liquidity crisis substantially increased the leverage of international actors (EU institutions and financial markets), which strengthened the hand of the government and the employers. Social dialogue became even more marginalised. The government passed a package of austerity measures (UL RS 40/2012) that reduced the welfare state and public sector wages. The public sector unions called a strike that ended with two strike 
agreements (UL RS 38/2012, UL RS 40/2012) ensuring lower wage cuts, milder cuts in social rights and preservation of the quality of social services. Supported by external actors, the government designed and implemented a so-called 'bad bank' (UL RS $105 / 2012$ ) that dealt with non-performing loans at an enormous fiscal cost and with dubious efficiency. A fiscal rule demanding a balanced budget was enacted (UL RS 47/2013, UL RS 55/2015). The right to referendum was restricted and referendums on fiscal issues were excluded (UL RS 47/2013). Finally, 15 companies were scheduled for quick privatisation in order to please the international financial markets. The trade unions protested against these measures, to little avail.

Despite the virtual collapse of social dialogue during 2008-13, two major reforms were adopted with consensus of the social partners in the ESC: the pension reform of 2012 (UL RS 96/2012) and the labour market reform (UL RS 21/2013). The pension reform was similar to the one that had failed in 2010 but minor concessions, such as a lower retirement age for people who started working before the age of 18 , were allowed. The labour market reform of 2013 flexibilised regular employment but also sought to limit the use of atypical work and improve the security of precarious workers (see Case Study 2 in Chapter 7 in this volume).

\subsection{Impact of Industrial Relations on Economic and Social Convergence (2008-13)}

There was little progress in economic or social convergence during the crisis. On the economic convergence front, two accomplishments of social dialogue should be noted. First, the agreement on short-time working that enabled companies to retain skilled and experienced employees and, second, the pension reform of 2012 that stabilised the share of public expenditure for pensions (UMAR 2017). On the social convergence front, one of the rare areas of progress was the increase in the minimum wage, which improved the income security of low-paid workers. Trade union interventions also helped to preserve some past achievements. One of these was the rejection of mini-jobs that threatened to expand less formal work arrangements in the traditional service sectors, in which female workers are predominant, thereby increasing gender inequality. Resisting the government's unilateral measures, the trade unions were sometimes capable of achieving more balanced outcomes in terms of social convergence that mainly benefited vulnerable groups that are not their core constituency. For instance, after having to concede on the flexibilisation of standard employment, trade unions managed to include in the 2013 labour market reform a host of protective measures for non-standard workers. Similarly, the public sector unions had to accept wage cuts in 2012, but managed to obtain a strike agreement that preserved high quality public sector services and social rights. When, however, the government and the employers, supported by external actors, managed to impose certain measures - reform of social assistance, fiscal rule, austerity measures, 'bad bank' - without mediating them through social dialogue, the outcomes often led to social divergence and were of dubious value for economic convergence. 


\subsection{Revival of Economic Growth and Social Dialogue in Dependent Capitalism (Post-2013)}

During the crisis the downside risks of pre-crisis investment strategies based on bank financing, with heavy borrowing on the part of domestic banks on international markets, were revealed (Masten 2010). As an alternative way of financing economic development, FDI became a constitutive element of the government's development strategy (Government of Republic of Slovenia 2015), the European Commission and Council recommendations (2014/C 24/22; COM (2015) 273; 2016/C 299/22; 2017/C 261/23) and even the strategy of the social partners (UL RS 29/2015).

Economic growth returned in the second half of 2013 and further accelerated in 2017. After several years, the social partners signed a new Social Pact for 2015-16 (UL RS 29/2015) based on recommendations of the European Commission and the Council (2014/C 24/22), which was considered instrumental in sending a positive signal to international investors. The pact stressed the need to boost domestic demand, but also stronger participation in global value chains and FDI promotion. The government pledged that there would be no reform regarding key issues in certain areas that are of special importance to the social partners. In the area of social policy the pact promised a reform of the health system, with stronger solidarity elements. However, the pact was never signed by the main employers' organisation and was short lived as other employers' organisations cancelled it in late 2015 after the trade unions managed to have the minimum wage redefined (UL RS 92/2015) by submitting the popular initiative to the parliament. Social dialogue in the tripartite ESC has brought about some other minor reforms. The 2016 mini tax reform was not agreed with the social partners. The trade unions were not entirely satisfied, although the reform contained some of the elements they demanded, such as an increase in the corporate tax rate, which had been lowered during the crisis. The latter measure was heavily opposed by two employers' organisations. However, lower income tax for the upper-income brackets benefited the large corporations that publicly supported the reform. Other legislative outcomes entailed the reregulation of student work (UL RS 95/2014) by establishing a minimum hourly rate and integrating it into the social insurance system. The mini labour market reform of 2017 strengthened the Labour Inspectorate in cases of unlawful use of atypical contracts and (non-)payment of wages.

Substantial flexibilisation of standard employment (Figure 10.2), a corporate tax reduction in 2012 and lower taxation for high salaries in 2016, generous subsidies for foreign investors and the government's active engagement in support of FDI, among other things, can be regarded as measures to attract FDI. The share of FDI in gross domestic product (GDP) has increased recently, but was mainly due to takeovers of Slovene companies, though some notable greenfield FDI also took place in 2017. Although the total amount of FDI is still low by international accounts, Slovenia may have come full circle and started to converge towards the group of dependent market economies.

As the shift towards FDI is relatively recent and coincided with the crisis, the outcomes in terms of social convergence are difficult to discern. It appears that, with the 2013 labour market reform, Slovenia tried to compete with the Visegrád countries. Nevertheless, Slovenia has not been overly successful in its attempt to join the race to the bottom, because Slovakia and Hungary flexibilised their labour codes even more (Figure 10.2). Nevertheless, not all features of a turn towards a dependent market economy (see section 


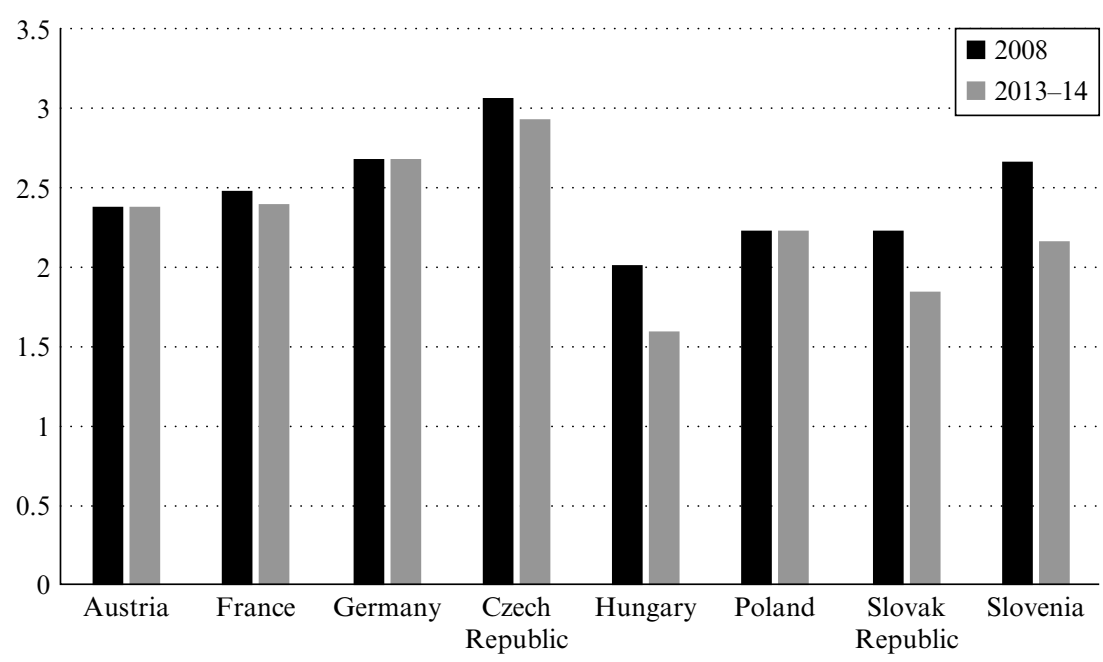

Source: Organisation for Economic Co-operation and Development (OECD).

\section{Figure 10.2 Employment protection legislation, Slovenia and selected EU member states, 2008 and 2013-14}

1) as regards social convergence have been realised. Unlike in other CEE countries that adopted a flat-tax system, income tax remains progressive and cuts for higher-income brackets were at least partially compensated by a higher tax on corporate profits. Also, although budget revenues were reduced by tax reforms and generous incentives in order to attract foreign investors, Slovenia remains the most generous welfare state in central and eastern Europe (Figure 10.3).

Finally, in so far as social dialogue counts as an indicator of social convergence, the story of convergence towards the model of a dependent market economy seems less persuasive. First, while many sectoral collective agreements were cancelled during the crisis, the post-2013 period saw their renegotiation and the collective bargaining coverage rate increased to around 75 per cent, with social partners in the private sector expecting a return to almost total coverage. Secondly, after a change in the leadership of the main employers' organisation in the course of routine elections in 2017 - the winning electoral programme of the new administration was based on the promise of a more constructive dialogue with the trade unions - the main employers' organisation and the largest private sector trade union confederation were intensively negotiating a new social pact, including detailed commitments regarding key variables, such as value added, exports and wages. The government (especially the Ministry of Labour and Social Affairs) also supported the negotiations. The return to the pacts of the 1990s and early 2000 s does not seem very likely, not least because the interests on the employers' side currently are much more diverse. While the main employers' organisation, in which influential large manufacturing companies seem to favour a comprehensive pact that could contribute to the stability of their business environment, some employers' organisations dominated by certain service sector companies (including temporary work agencies) seem less keen on such an agree- 


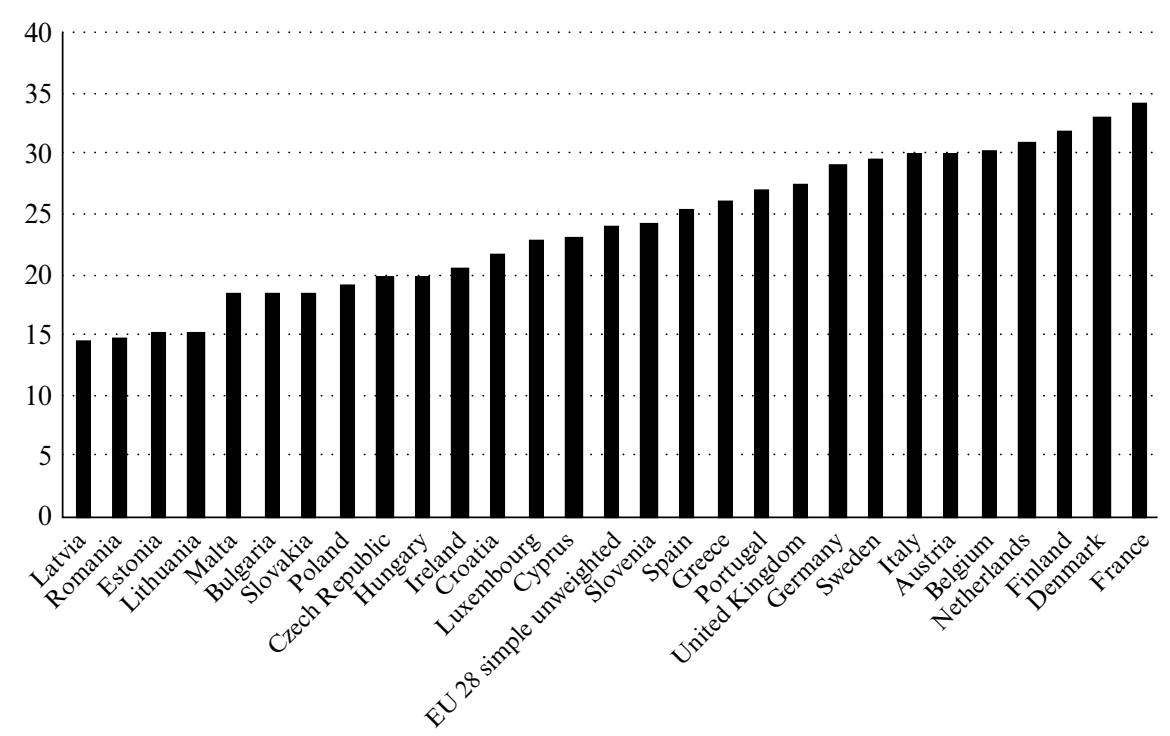

Source: Eurostat.

Figure 10.3 Social expenditure as a percentage of GDP, Slovenia and EU28, 2014

ment. Nevertheless, there is interest on both the labour and the business sides, which suggests that neo-corporatist concertation in Slovenia is not necessarily a thing of the past.

In summary, the recent turn of events appears ambiguous. Some measures (courting international investors, tax reform favouring large companies, and competitive flexibilisation of the Labour Code) suggest that a partial shift towards the dependent market economy has occurred. However, important features that distinguish the Slovene model from other CEE countries were preserved (progressive taxation and higher social expenditure) or even resuscitated (collective bargaining and social dialogue) in the postcrisis period.

\subsection{Impact of Industrial Relations on Economic and Social Convergence (Post-2013)}

Social dialogue recently became an element of stabilisation and largely supports the government's policies, including the measures for attracting FDI. Most of the tripartiteagreed measures in the post-2013 period target both economic and social convergence. For instance, the reregulation of student work is viewed by some employers as levelling the playing field because now certain social contributions are also paid for this scheme, while trade unions saw it as a step towards rolling back precarisation. The same holds for the mini labour market reform of 2017 that contributes to social convergence by helping to convert illegal non-standard (and precarious) forms of employment into standard employment and to economic convergence by preventing unfair competition on the part of employers using these labour arrangements. Redefinition of the minimum wage, 
warranting the payment of certain wage allowances in addition to the minimum wage, however, strengthened mainly social convergence as it marginally improved the income security of those at the bottom of the wage distribution.

\subsection{Conclusion}

During the early period in which the basic institutional framework of the Slovene economy was established, economic and social convergence were closely intertwined, mediated by social dialogue. This mediation, on the one hand, provided for an institutional setup that prevented a sharp rise in inequality and a socially less disruptive transition to capitalism. On the other hand, it enabled a restructuring of the economy without excessive reliance on foreign investment; it was also essential for a smooth accession to the euro zone. As the practice of negotiating economic and social policies through social dialogue was weakened and collective bargaining decentralised progress in the area of social convergence after 2004 slowed down, while economic convergence proceeded only by piling up risks associated with increasing foreign indebtedness. These accumulated risks materialised after 2008. The ensuing crisis severely restricted room for compromise, which undermined social dialogue and in many areas set in motion a process of downward social divergence. Since 2004 and especially after 2008 trade union actions were often aimed at safeguarding the past achievements of social convergence against unilateral government interventions. During the post-2013 recovery, social dialogue was revived, which indicates that the social partners still appreciate the opportunities it provides in both social and economic convergence. It remains to be seen, however, whether the close relationships between the two areas will be re-established in the post-crisis period.

\section{OUTCOMES}

In this section we try to illustrate the impact of developments examined in the previous section by presenting trends in selected indicators of social convergence and linking them to industrial relations. We will examine the following areas and indicators: wage inequality and income inequalities; gender inequality; and health insurance. The issue of precarious work is taken up in Case Study 2 in Chapter 7 of this volume.

\subsection{Wage and Income Inequalities}

Wage inequality - as regards regular full-time employment - is not very high in Slovenia, although it increased after 2000 until 2010. This outcome can be directly linked to the early agreements on incomes policies that brought about a certain wage compression and the institution of the minimum wage, which was agreed as part of the social pact for 1995 and was deliberately allowed to increase faster than other wages by the social partners. As shown in Figure 10.4, after sharply increasing in the first half of the 1990s, wage inequality stabilised and even began to decline slightly precisely at the time the first agreement on incomes policy was implemented. This development is a good example of the interaction of economic and social convergence in the early period of Slovene transition: the trade unions accepted slower wage growth, which helped companies to finance 


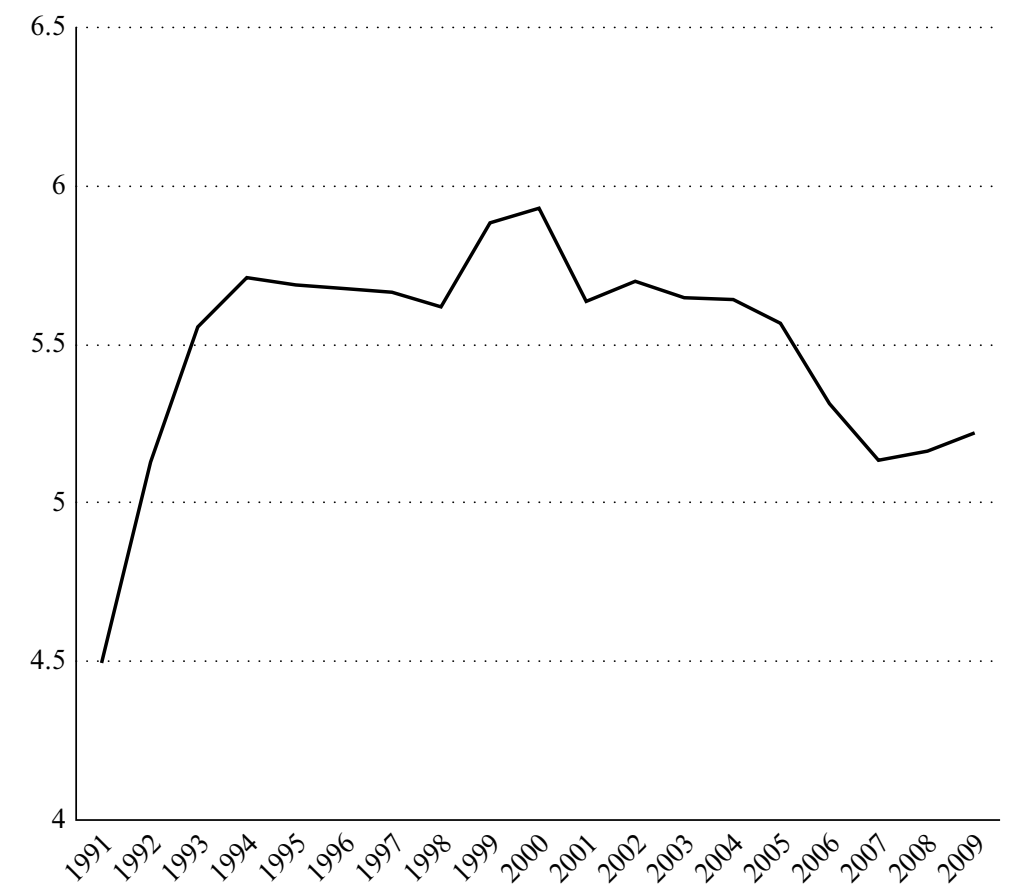

Note: * The figure depicts the D80/D20 ratio calculated for gross wages. The data include all employees whose wage earnings exceeded the general tax allowance and (unadjusted) earnings of part-time workers. The data were collected on a yearly basis and do not indicate the timespan in which the wage income was created within a given year, which means that even those who worked for only a few months in a given year are included, provided that their earnings exceeded the general tax allowance (cf. Stanovnik and Verbič 2012).

Source: Stanovnik and Verbič (2012).

Figure 10.4 Wage income quintile share ratio, Slovenia, 1991-2009

their investments, supported government policies targeting inflation and underpinned export competitiveness, and in exchange gained influence over the government's social and labour market policies (for example, minimum wage, holiday pay and unemployment protection), which fostered social convergence.

Two factors seem important to explain the increase in wage inequality between 2000 and 2010 (Figure 10.5), both of which indicate that this unfavourable social convergence trend is linked to the decreasing intensity of social dialogue in this period. The factors are the abandonment of the incomes policy agreements from the mid-2000s and the decentralisation of collective bargaining that took place at approximately the same time. Both developments are directly related to social dialogue as they reduced the scope for solidaristic wage policy at the national level and thus contributed to an increase in wage disparities within as well as between sectors. As to the latter, the difference between the highest and lowest average wage in industry increased from 1.85 in 2000 to 2.46 in 2007 (UMAR 2016). Other factors, such as the spread of precarious work, probably also contributed to the increase in wage inequality: the share of low-wage earners among 


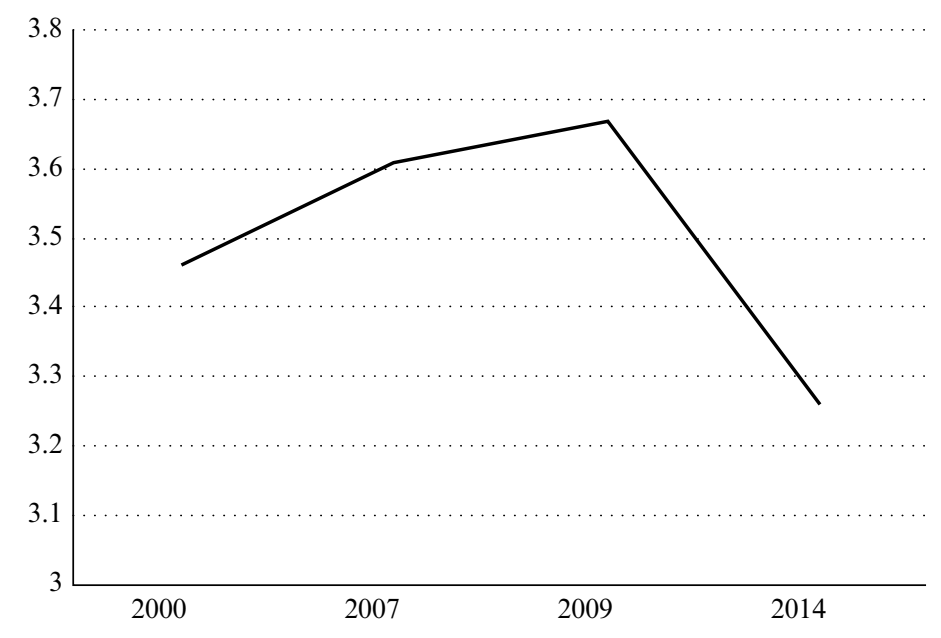

Source: UMAR.

Figure 10.5 Inequality of gross wages: ratio of 9/1 decile, Slovenia, 2000-2014

temporary workers (14.5 per cent) in 2014 was more than double that of permanent employees (32.9 per cent, according to Eurostat). Also, despite the formal equalisation in status, agency workers tend to be paid less than regulars as agencies often find ways around the law which the agency workers do not report owing to their exposure to, and dependency on, the employer (Breznik 2018).

Industrial relations developments after 2008 sought to address both the issue of wage inequalities and the problem of precarious work. In 2010, following pressure from the trade unions, a 23 per cent increase in the minimum wage was applied, which strongly reduced the inequality of full-time employees (Figure 10.5). Although precarious work was not eradicated from the Slovene labour market, the social partners put a serious effort into addressing this problem in the 2013 labour market reform (see Case Study 2 in Chapter 7 in this volume).

The tax system was also, to a large extent, shaped through social dialogue. The increase of the general tax allowance that disproportionally benefited those at the bottom of the wage distribution was one of the elements commonly exchanged for wage restraint during the 1990s and early 2000s, and further reduced income inequalities (Stanovnik and Verbič 2012), thus enhancing social convergence. The latter was also supported by successful trade union mobilisation against government attempts to introduce the flat tax, which would have resulted in a sharp increase in income inequality. Although this action was merely defending the progressive tax system without bringing any further progress, it was probably the single most important industrial relations development in the area of tax policy because it prevented a detrimental shift towards downward social divergence. Another factor that contributes to low-income inequalities is a relatively narrower ratio between the lowest and highest pensions (Murn 2017), an element that was strengthened in the process of social dialogue leading to the 2000 pension reform.

Throughout the post-2000 period income inequality in Slovenia was among the lowest 


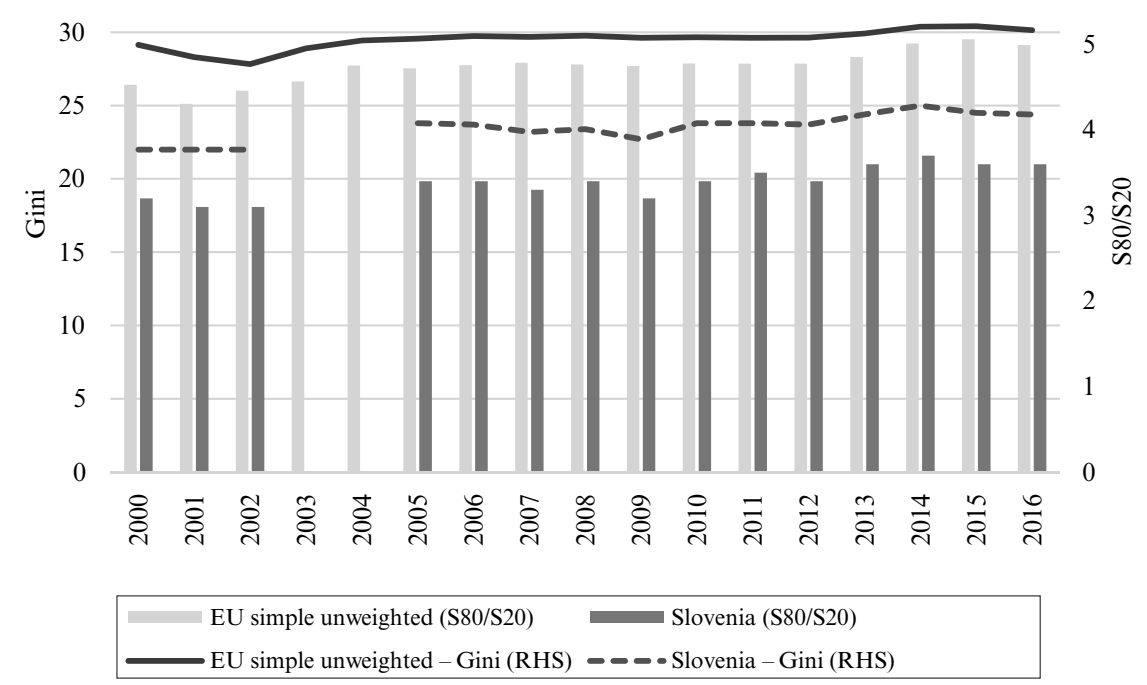

Source: Eurostat.

Figure 10.6 Income inequality ( S80/S20 and Gini coefficient), Slovenia and EU28, 2000-2016

in the EU, although it was gradually increasing (Figure 10.6). This downward trend in social convergence was due at least in part to an increase in wage inequality. However, despite a decrease in wage inequality in the post-2010 period, income inequality and poverty kept rising. Prolonged crisis and increases in some of the most precarious forms of work - such as people pushed into (also bogus) self-employment because they were unable to find any other form of employment - played a part in the recent increase in poverty rates (Murn 2017). Since 2010 the government has heavily subsidised these transitions from unemployment to self-employment, a policy against which the unions protested, but to no avail. The risk of poverty is much higher among the self-employed than among those in dependent employment (27.9 against 4.6 per cent, respectively, in 2013, according to the Statistical Office of the Republic of Slovenia - SURS). Also, poverty increased due to regressive changes imposed on social assistance. Particularly inimical to any form of social convergence was the Social Assistance Benefits Act that the government adopted in 2010, despite trade union protests. One of the harshest provisions required that social assistance be repaid and recovered from any inheritance after the death of the beneficiary, which prompted claimants to renounce social assistance. Indeed, despite the crisis the number of claimants actually declined (Leskošek and Dragoš 2015). The harsh austerity measures that further reduced welfare state provisions and were unilaterally imposed by the government with the tacit support of employers and the European Commission intensified the pressures on the most vulnerable groups in society, dependent on social assistance, and certain segments of pensioners. Similarly to wage inequality, deterioration in once favourable trends of social convergence in the area of income inequalities and poverty can thus to a large extent be traced back to policy measures adopted by the government and without proper coordination with the social partners. 


\subsection{Gender Inequalities and Work-Life Balance}

Although there is still a long way to go before Slovenia achieves gender equality, this is one area in which important social achievements were won during the period of socialist self-management. During the transition period the position of women worsened and inequalities increased, mainly owing to intensification of paid work without a corresponding decrease in domestic labour (Penner et al. 2012). However, several steps that supported social convergence and/or defended past achievements were also taken in the sphere of industrial relations after 1990.

Slovenia traditionally has a relatively low gender employment gap, which amounted to some 6.6 percentage points in 2016 (Eurostat); the country has even slightly improved its performance in comparison with other EU countries since the mid-2000s. In addition, part-time contracts for less than 20 hours a week are not very widespread among female workers in Slovenia (Figure 10.7). This is partially the result of relatively good, affordable childcare provision, which is an important building block of a de-familialised welfare state model, as it provides a good alternative to familial care after parental leave (which is of moderate duration) and thus facilitates women's continuing employment (Javornik 2016). The childcare system was inherited from the socialist period but trade unions had to defend it against government encroachment during the crisis period. For example, public sector workers went on strike against the government's attempt to lower the high standards and norms that regulate public education and other public services in the context of austerity measures. While the trade unions had to concede on certain wage cuts (UL RS 38/2012), the final strike agreement (UL RS 40/2012) included the withdrawal of austerity measures lowering standards and norms, which preserved an important accomplishment of social convergence related to gender equality.

While government-imposed austerity measures were formally gender neutral, many affected women more than men and should thus be treated as detrimental to social

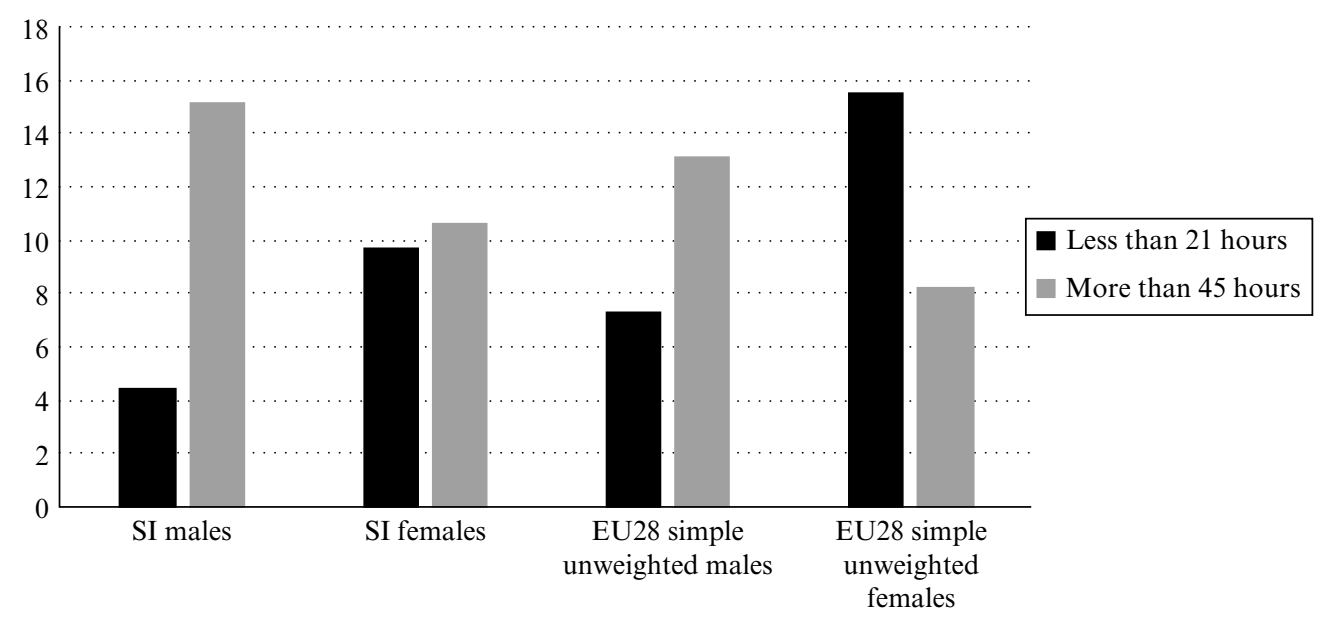

Source: European Working Conditions Survey (EWCS).

Figure 10.7 Working time distribution by gender, Slovenia and EU28, 2015 
convergence in the area of gender equality. For example, many welfare state provisions that improve work-life balance and are an important element of social convergence with regard to gender equality were weakened: family benefits, benefits for child nursing and care leave and child benefits were cut, fees for the second child's kindergarten were increased, and so on (Humer and Roksandić 2013). In the agreement that ended the public sector strike in 2012, the public sector trade unions managed to include certain provisions that made curtailments of welfare rights less severe than originally announced and reached a compromise with the government to lift these austerity measures once the annual rate of GDP growth exceeds 2.5 per cent, which at least partially preserved the past results of social convergence in this sphere.

Another important defensive action in the area of industrial relations related to safeguarding the level of social convergence attained in gender equality was the successful trade union campaign against the introduction of mini-jobs in 2011. The impact of this rejection of mini-jobs cannot be assessed directly because no legislative change occurred. Given that a similar arrangement accessible only to students is most widespread in the low-paid service industries - such as food retail and hospitality, which feature a large share of female employment - we may surmise that if the reforms had been passed, this employment arrangement would disproportionally impact women. The trade unions were deeply aware of the gendered aspects of the mini-job proposal and during the campaign consistently presented it as a measure undermining gender equality (Böhm 2011).

Many of the provisions conducive to social convergence in terms of gender equality at the workplace are contained in the Labour Relations Act, which was closely coordinated by the social partners in the tripartite ESC in the period from 1997 to 2001 and passed in 2002. The law provides a relatively high level of rights related to work-family balance, such as special protection for women during pregnancy, birth of a child and breastfeeding (the burden of proof is on the employer), and ensures rights related to parenthood for all workers. For example, the law guarantees the preservation of all work-related rights and improvements in these rights for employees on parental leave. Furthermore, the right to parental leave is combined with a decent parental leave compensation and is increasingly arranged in a way that stimulates the take-up of paternity leave (Poje, Vuga Bernšak and Štamfelj 2016).

Before 2003, when the Labour Relations Act came into force, the general collective agreement for the private sector (UL RS 40/1997) contained certain provisions for a better balance between work and family life. Currently, sectoral collective agreements also promote social convergence with several provisions in support of gender equality. Some are aimed at enabling a better work-family balance and either encourage men to take a more active role in family-related obligations or enable a reconciliation of work and family obligations that are in practice most often shouldered by women. Collective agreements for the metal, electric and metal materials industries stipulate the right of single parents to decline overtime. A recent annex to the collective agreement for the trade sector demands that employers announce worktime schedules in advance, limits Sunday work to 15 days per year and prohibits it for parents of small children or people with other caring obligations (UL RS 69/2017). Some collective agreements, for example, in tourism and hospitality and banking or postal services, demand more favourable working time for workers with caring obligations. Management prerogatives regarding changes of workplace for workers with caring responsibilities are circumscribed in 
collective agreements for tourism and hospitality, printing and publishing. Others, for instance, the collective agreement for the textiles, apparel and footwear sector, provide workers with school-age children the right to take at least one week of their annual holidays during school holidays. Virtually all collective agreements provide for paid days or for hours off work for personal reasons, such as marriage, death or illness in the family and childbirth. The collective agreement for the textiles, apparel and footwear industry demands equal access to training and education regardless of gender, age or employment arrangement. Collective agreements for the metal industry and metal materials demand that the employer report on measures for fighting all kinds of discrimination, including gender discrimination. Although there is ample room for further improvement in this area, most of the measures are covered by at least some sectoral agreements (Kresal and Kresal 2015).

The unadjusted gender pay gap in Slovenia is among the lowest in the EU, which together with a relatively low share of women in marginal part-time employment (Figure 10.7) makes the overall gender pay gap the second lowest in the EU. The low gender pay gap in Slovenia is to a large extent explained by the high proportion of women working in the public sector, where wages are higher, although they still tend to be paid less than their male colleagues (Penner et al. 2012). Strong trade union organisations in the public sector are thus conducive to a low gender pay gap. Several actions that helped social convergence regarding equal pay were undertaken by the social partners. The Labour Relations Act of 2002, which was thoroughly coordinated by the social partners, explicitly demands equal pay for equal work. Also, some collective agreements, for example, collective agreements in the textiles, apparel and footwear industry or the non-metal materials industry, demand that employers report to the trade union on pay policy, which provides a solid basis for monitoring gender pay inequalities (Kresal and Kresal 2015).

'Soft tools' aimed at fighting pay discrimination have also been applied by the trade unions. The largest trade union confederation in 2005 explicitly called for inclusion of provisions on pay equality in sectoral collective agreements. The Social Pact for 2007-09 explicitly assigned the task of encouraging the policy of equal pay for equal work to the employers' organisations. Trade unions are involved in research projects on wage differentials between men and women and have also issued several publications containing analyses of the gender pay gap and examples of best practices from abroad (Humer and Roksandić 2013). The largest trade union confederation and the largest trade union in the public sector both have committees for equal opportunities, and since 2007 the former has awarded a special annual prize for achievements in the area of gender equality. In contrast, the government's measures imposed during the post-2008 crisis in general contributed to the increasing gender pay gap. Most important in this respect were again the austerity measures that reduced wages in the public sector, which impacted mainly women. Furthermore, although stated in a gender neutral manner, austerity measures that repressed pension increases and reduced entitlement to minimum pension allowances increased poverty among older women and reduced their economic independence (Humer and Roksandić 2013).

In summary, regarding the labour market participation of women, as well as the gender pay gap, meaningful social dialogue or defensive trade union actions were largely conducive to gender equality. However, unilateral measures for fiscal consolidation rarely took account of the gender dimension. 


\subsection{Health Insurance System}

The social partners in Slovenia participate in the shaping and managing of social protection, especially in so far as these are financed by wage contributions, at three levels. First, they are involved in the social dialogue that takes place in the national tripartite institutions where legislation, including laws that shape the health system, is discussed and negotiated. Second, their representatives play an important role in the administration of social insurance through participation in the tripartite governing boards of social insurance institutions. Finally, similar to other organisations, they are engaged in the management of the organisations that provide the associated services (for example, health centres, hospitals and clinics).

The Slovene health system is far from ideal and has problems of its own, such as long waiting times for some specialist services and high workloads, especially for nurses. Nevertheless, the social pillar indicators provide a reasonably favourable picture: the share of out-of-pocket household expenditure on health care, at 12.52 per cent of total health-care expenditure (roughly 71 per cent is financed from public sources and some 15 per cent from supplementary insurance) is among the lowest in the EU and the share of those reporting unmet medical needs, which was already very low in 2005, has further improved and was the third lowest, behind only the Netherlands and Austria, by 2015 .

These good results are largely due to the involvement of the social partners at the national level and in the governing bodies of health insurance institutions. As noted above, one of the most heartening reforms of the Social Pact for 2003-05, which was, together with incomes policies and the agreement with the public sector trade unions, instrumental in early adoption of the euro, was the promise to strengthen the egalitarian elements in the health system. Hence, the social partners agreed to abolish supplementary health insurance and a corresponding enlargement of compulsory insurance. A similar pledge can be found in the short-lived Social Pact for 2015-16, but at the time of writing the promise had not yet been delivered. Nevertheless, smaller changes to the Law on Health Care and Health Insurance from 2007, which was agreed by the social partners in the ESC, provided for the payment of supplementary health insurance to those with the lowest incomes from the state budget. This at least partially alleviated the regressiveness of health-care insurance and reduced the occurrence of situations in which those at the bottom end of the income distribution are faced with the alternative of paying out of pocket or going without health services when in need.

Of even greater importance to this good performance, according to the two indicators mentioned above, is the participation of the social partners in the management board and assembly of the health insurance institution (ZZZS), in which they hold 35 out of 45 seats. This is important because the entitlements covered by basic, compulsory health insurance are only generically determined by the law. They are detailed in the Rules on Compulsory Health Insurance adopted by the ZZZS assembly, and thus the social partners, with the consent of the Ministry of Health. Trade union representatives in the ZZZS assembly are constantly fighting for updates of the list that details health services covered by compulsory health insurance. These updates are important for adding new medical services and technologies to the list of services covered by the compulsory health insurance as soon as they become available. This is also of major importance when it 
comes to which medical needs are met and how much households spend on health services out of their own pockets (which is precisely what the mentioned indicators show).

\section{CASE STUDY: FOREIGN DIRECT INVESTMENT, INTERNATIONAL TRADE UNION COOPERATION AND SOCIAL CONVERGENCE}

Since the start of transition Slovenia has been an export-orientated economy. However, unlike other CEE countries, it was not very keen on attracting foreign investors within the framework of privatisation. Company restructuring was, to a greater extent than in other countries in the region, financed by domestically generated funds, in large part supported by early incomes policies. However, more recently, the Slovene government's development strategy has envisaged a stronger role for foreign direct investment and has been commended by the European Commission.

Cross-border capital flows in general and particularly foreign direct investment are commonly sought as a lever of economic convergence because they allow the recipient country to expand production and investment, to benefit from the transfer of knowledge and so on (ECB, 2012), although Slovene academics and policy-makers are not always unanimous in their views on the benefits of FDI for the national economy (Mencinger 2003), and fears of losing national economic sovereignty have often been raised. The superior efficiency of multinational affiliates in terms of productivity, research and development $(\mathrm{R} \& \mathrm{D})$ and capital intensity, as well as wage premiums seems to be less in dispute (Damijan and Kostevc 2017; cf. Chapter 2 in this volume, for findings on multinational wage premiums in Estonia). The benefits of FDI in terms of social standards are even less straightforward and fears that strong dependence on FDI in central and eastern Europe could present an obstacle to social convergence cannot be dismissed (cf. Chapter 2 in this volume for an extensive treatment of the social impacts of FDI in CEE countries). Competition for FDI among CEE countries is well documented, as is the problem of 'coercive comparison' by which multinationals extract concessions from workers, raising fears of a race to the bottom deleterious to the process of social convergence (Bohle 2009; Van Klaveren et al. 2013). More broadly, international operations of capital (competition on export markets, penetration of multinationals and posting of workers) intensify competition between local workforces, which could, however, also encourage national trade unions to strengthen mechanisms of transnational coordination and solidarity (Marginson and Meardi 2012; Meardi 2012).

This case study first examines the effects of enhanced penetration of multinationals on social standards at the company level, in general, and social dialogue, in particular. We also examine the international cooperation of Slovene trade unions in response to the international operations of employers (competition on export markets, FDI and posting of workers). We would like to gauge the extent to which international trade union cooperation can withstand the pressure of transnational employers with regard to social standards at the sectoral and/or company level. The empirical data for the study were collected in standardised interviews with 11 sectoral trade union leaders, conducted in early 2018. 


\subsection{Social Dialogue and Social Standards in Foreign-owned Companies}

Social dialogue in Slovenia plays an important role in advancing social convergence as well as preserving past social achievements. Hence, we inquired into the effects of foreignowned companies in comparison with domestically owned companies on conditions for social dialogue at the company level. The results are summarised in Table 10.1. In the survey we adopted a very broad definition of foreign-owned company, as a company owned by a foreign entity that operates in Slovenia and at least one other country. Foreign-owned companies are present in nine out of the 11 sectors organised by the trade unions we surveyed, with the strongest presence in manufacturing and trade.

Most trade unionists find no major differences when it comes to difficulty of negotiations with foreign-owned companies. However, many (five) unionists observed that even when companies are managed by Slovene nationals, they are considerably less autonomous than managers of domestic companies, as crucial decisions are taken at the headquarters located abroad: 'Generally they do talk to us, but they are essentially postmen ... They have no direct executive power' (Trade Union of Textile and LeatherProcessing Industry of Slovenia, STUPIS).

No clear pattern emerged regarding coverage with company-level collective agreements. Most respondents mentioned that such coverage tends to be more dependent on

Table 10.1 Impact of foreign-owned companies on enterprise-level social dialogue, Slovenia, 2017-18

\begin{tabular}{lllcccc}
\hline & $\begin{array}{l}\text { FDI } \\
\text { presence }\end{array}$ & $\begin{array}{l}\text { Sectoral } \\
\text { collective } \\
\text { agreement }\end{array}$ & $\begin{array}{c}\text { Company- } \\
\text { level collective } \\
\text { agreement } \\
\text { coverage }\end{array}$ & $\begin{array}{c}\text { Difficulty } \\
\text { of collective } \\
\text { bargaining }\end{array}$ & $\begin{array}{c}\text { Ease of } \\
\text { recruitment }\end{array}$ & $\begin{array}{c}\text { Cooperation } \\
\text { with } \\
\text { employee } \\
\text { representatives }\end{array}$ \\
\hline KŽI & High & Yes & 0 & ++ & 0 & + \\
STUPIS & Medium & Yes, extension & 0 & - & - & - \\
SDE & Low & Yes & $/$ & $/$ & $/$ & $/$ \\
SKEI & High & Yes, extension & + & + & - & + \\
SDGD & Low & Yes & + & 0 & 0 & ++ \\
KNG & High & No & 0 & 0 & 0 & 0 \\
SDPZ & Low & Yes & $/$ & - & 0 & + \\
GIT & Medium & Yes, extension & 0 & 0 & 0 & 0 \\
SDTS & High & Yes, extension & - & 0 & 0 & + \\
SINLES & Low & Yes, extension & 0 & $/$ & $/$ & $/$ \\
SFOS & Medium & Yes & - & - & - & - \\
\hline
\end{tabular}

Notes:

I = no data.

Indicator of social dialogue $(+)$ better in foreign-owned companies, $(++)$ much better in foreign- owned companies, $(0)$ no difference between foreign-owned companies and domestic-owned companies, $(-)$ worse in foreign-owned companies, much worse in foreign-owned companies (-).

The trade unions surveyed organise the following sectors: agriculture and food industry (KŽI), textile and leather processing (STUPIS), the energy sector (SDE), metal and electrical industry (SKEI), construction (SDGD), chemical, non-metal and rubber industries (KNG), transportation and telecommunications (SDPZ), catering and tourism (GIT), trade (SDTS), wood processing (SINLES) and financial organisations (SFOS). 
company size than on ownership (better coverage in larger firms). Five out of nine sectorlevel unionists observed that foreign-owned companies often press for decentralisation of collective bargaining, but the same attitude is observed with domestic-owned companies. Decentralisation here means that sectoral collective agreements are retained but more issues are left to company-level bargaining.

Some respondents reckoned that recruitment is more difficult in foreign-owned companies (cf. Chapter2 in this volume, for trade union presence in multinationals in Estonia). Nonetheless, even some of those that see no major differences between foreign-owned companies and domestic-owned companies noted that certain foreignowned companies find trade unions incompatible with their business models and thus try to avoid a union presence by 'soft methods'. For example, some foreign-based retail discount chains have established the institution of 'workers' confidant', who is supposed to assume the role normally performed by a trade union representative, and the company encourages workers with work-related problems to turn to him or her (instead of turning to the union). In general, some home-country effects could be discerned here as respondents often explained that companies from continental western Europe are comparatively more interested in cooperation with employee representatives. Foreign-owned companies are not hostile towards employee representatives, but seem to prefer works councils over trade unions. This might, however, constitute a problem with Slovene trade unions as they are often reluctant to establish a works council if the trade union in the company is not strong enough because they fear that the management will be able to manipulate the works councillors. However, when directly asked whether there are any home-country effects regarding their relationships with trade unions, only three responses were positive, but one in an unexpected direction, as German firms were perceived as more short-term orientated in their cost-cutting efforts, while American and Swiss owners were said to appreciate product quality more.

Instead, an indication of host-country effects emerged, as a large majority (six out of nine $^{3}$ ) observed that foreign-owned companies respect the law and collective agreements much more strictly than domestic-owned companies: 'The law is the law and the collective agreement is the collective agreement. You only have to threaten that you will sue them over something that is written there and if confirmed by their lawyers, then that is that' (Hospitality and Tourism Trade Union, GIT) and 'if there are any breaches, then the foreigners will make it right immediately, while our compatriots often want to fool around' (Retail Workers Trade Union of Slovenia, SDTS).

Another indication of the importance of host-country industrial relations for either upward social convergence or the erosion of social standards when it comes to the influence of foreign-owned companies was provided by the answers to the question on overall impressions concerning whether foreign-owned companies bring better social standards. The opinion of two out of nine respondents was that foreign-owned companies erode standards in the branch, while one thought that they improve them. The other six, however, claimed that foreign-owned companies bring neither better nor worse standards, and four of them explicitly claimed that standards are dependent on the established standards in the country and/or the posture of the trade union:

The Czechs ... are tough negotiators, but you can get through to them. Though they will tell you that they almost do not have any union back there in Czechia. And when we talked about 
sick leave their CEO complained: 'When I am on the sick leave, I only get some 30 per cent while you get 80 or 90 per cent.' 'Well,' I said, 'then you should become a resident here and pay your taxes here and you'll surely get those 80 or 90 per cent.' We really had a good laugh. (Agriculture and Food Industry Trade Union, KŽI)

In Germanic countries . . . they respect social dialogue. . . . When they come here, they feel that they do not have to, that here they can behave in a different way, that we are a bit different and that they do not have to respect the trade union. But insofar as there is a trade union here and if it stands up for its rights and simply says: 'We are here, you have to listen to us, the law says this and that,' they will respect it. (Union of Transport and Communications, SDPZ)

In summary, while some union leaders claim that the quality of social dialogue in foreign-owned companies is better than in domestically owned companies, this is by no means a universal experience. Bargaining might be more difficult in foreign-owned companies and better coverage with company-level collective agreements is at least in part attributable to such companies' larger size. Also, foreign-owned companies in general prefer works councils to trade unions, which raises the question of control. Although we were able to identify some home-country effects, the most consistent result of this part of the study seems to be the existence of substantial host-country effects (cf. Chapter 2 in this volume for similar findings), including the presence and actions of the trade unions and collective agreements. The evidence thus suggests that domestic industrial relations play an important part in the preservation of the host country's social standards and thus in preventing downward social divergence.

\subsection{Transnational Cooperation of Trade Unions in Response to International Operations of Employers}

The presence of host-country effects, however, does not mean that the social standards of a given country, even if consolidated in collective agreements, cannot be changed under pressure of competition from other locations, be it competition on goods markets or competition of locations for fresh investment. In addition, the social standards in a given country are brought under pressure if employers take advantage of the vulnerable groups of workers, such as immigrants or posted workers. In the second part of the survey we thus collected evidence on the international coordination of sectoral trade unions in response to such pressures to uphold the achieved level of social standards or even foster upward social convergence across national borders.

\subsubsection{Organisations and forums for international cooperation}

The results show that, in addition to their links with the European Trade Union Confederation (ETUC) via the national confederation, sectoral trade unions in Slovenia tend to engage in lively cooperation extending beyond national borders through their participation in European-level sectoral organisations (the European Federation of Trade Unions in the Food, Agriculture and Tourism, EFFAT; the IndustriAll Global Union; the European Federation of Public Service Unions, EPSU; and the European Federation of Building and Woodworkers, EFBWW) and global sectoral organisations, regional forums and bilateral channels (especially with trade unions from the former Yugoslavia, Germany, Austria and Italy), while opportunities 
Table 10.2 Channels of international trade union cooperation, 2018

\begin{tabular}{lccccccc}
\hline & & Global & European & Regional & Bilateral & EWCs & $\begin{array}{c}\text { Plans to extend } \\
\text { cooperation }\end{array}$ \\
\hline KŽI & $\mathrm{X}$ & $\mathrm{X}$ & $\mathrm{X}$ & & & $\mathrm{X}$ & \\
STUPIS & $\mathrm{X}$ & & $\mathrm{X}$ & & & & \\
SDE & $\mathrm{X}$ & $\mathrm{X}$ & $\mathrm{X}$ & $\mathrm{X}$ & & & \\
SKEI & $\mathrm{X}$ & $\mathrm{X}$ & $\mathrm{X}$ & $\mathrm{X}$ & $\mathrm{X}$ & $\mathrm{X}$ & \\
SDGD & $\mathrm{X}$ & $\mathrm{X}$ & $\mathrm{X}$ & & $\mathrm{X}$ & $\mathrm{X}$ & \\
KNG & $\mathrm{X}$ & & & & & & \\
SDPZ & $\mathrm{X}$ & & & & & $\mathrm{X}$ & $\mathrm{X}$ \\
GIT & $\mathrm{X}$ & $\mathrm{X}$ & $\mathrm{X}$ & & $\mathrm{X}$ & & \\
SDTS & $\mathrm{X}$ & & & $2 \mathrm{X}$ & $\mathrm{X}$ & $\mathrm{X}$ & \\
SINLES & $\mathrm{X}$ & & & & & & $\mathrm{X}$ \\
SFOS & $\mathrm{X}$ & & & & & & \\
\hline
\end{tabular}

Note: $2 \mathrm{X}$ indicates participation in two regional forums.

for the delegation of members to works councils seem underused, at least partly owing to the ambiguous attitude of some Slovene trade unions towards works councils in general (Table 10.2).

\subsubsection{Forms of cooperation}

The international cooperation of Slovene unions predominantly takes the form of exchanges of information and consultation on a wide array of subjects, and joint participation in training and education. Some trade unions are involved in the coordination of collective bargaining, usually by reporting on domestic developments. Many participate in 'soft' solidarity actions, such as sending petitions or delegations. Most trade unions are also involved in shaping common positions on issues of regulation at the EU level in dialogue with the European Commission via their European-level sectoral organisations.

\subsubsection{Impact on social convergence}

Information exchange and consultation are undoubtedly 'soft' tools. Nevertheless, they can be of great importance when employers try to lower social standards in the course of sectoral collective bargaining by referring to standards enjoyed by competitors in other countries that serve the same markets. Several trade unions involved in a kind of 'soft' coordination of collective bargaining by exchanging information on collective bargaining developments argued that the right information can often prevent deterioration of standards in competition with workers from other countries:

on one occasion, when we were bargaining on the sectoral collective agreement, the employers threw at us some data from abroad. But we told them outright that we are members of EFFAT and that we have the information and that they should not get too smart about it, because we know these things pretty well. And I must say that they stopped at that point when they saw that they cannot paint us pictures of how the situation is in Germany, Austria or Poland and the Czech Republic. (KŽI) 
The same holds in cases of company-level collective bargaining with subsidiaries of foreign-owned companies. As noted previously, Slovene managers of foreign-owned subsidiaries have less autonomy as decisions are usually taken at the foreign headquarters. However, demands from foreign owners are often an excuse for imposing pressure that could lead to downward divergence. The president of the metal and electrical industry union explains how strong international contacts can be effective for dissipating such claims and for coming up with counter-arguments to erosion of social standards:

In Zagorje they are a part of a multinational. They started to [make problems] with the company-level collective agreement and wanted to reduce workers' rights. The reason for that was allegedly 'the mother' - 'The bosses back in Germany demand it'. Well, in three hours I had the name of the president of their union and all the information and asked him to check whether the claims were true - and, of course, they weren't. [These channels] are very effective, if we only know how to use them. (Trade Union of the Electronics and Steel Sectors, SKEI)

Trade unions in home countries are usually interested in such cooperation in order to avert the attrition of social achievements at home by preventing a potential race to the bottom in competition with multinational subsidiaries abroad. International cooperation thus enables trade unions to preserve social standards in home countries by ensuring equal standards and rights in the host country, which may stimulate social convergence. One way to achieve this is to inform the host country representatives on the level of rights prevailing in the company and include them in foreign-owned companies' structure of employee representation or help them to establish one of their own:

When GERCORP was taking over SLOCOMP, the first contact was established as soon as the news came that GERCORP was shortlisted as a potential buyer. Within three days I received a request from the German works council for the contact info of the trade union in SLOCOMP. They established a connection ... before GERCORP actually owned the company. They explained the companies' system to them and the level of rights in GERCORP, the parent company, told them what they should be wary of and then included them in the EWC immediately after the takeover took place. (SKEI)

'[W]here our companies operate, say, in Croatia, Bosnia, Serbia, we help our colleagues in the trade sector to establish trade unions. ... We try to implant Slovene standards there because their standards are much worse' (SDTS).

International trade union cooperation can also help to safeguard social standards when companies try to take advantage of vulnerable groups, such as posted workers from low-income countries. This was the case with a joint action of Slovene and German construction unions that moved to prevent unlawful practices concerning the posting of workers from the former Yugoslavia to German construction sites by Slovene companies. After providing for the basic needs of workers who the Slovene informal temporary work agencies left on their own without paying them their due wages, the Slovene trade union first provided data to the German trade union, which then sued the Slovene companies. Later, the two unions consulted, on the basis of which the Slovene trade union cooperated with the government in shaping appropriate regulations for preventing such situations in the future.

Finally, besides their use in protecting established standards, international trade union links promote social convergence through the transfer of best practices. The Slovene 
trade union in the construction sector learned from its Austrian counterpart about the organisation and management of parity-based funds. Now it works hand in hand with the sectoral employers' organisation to persuade the government to provide funds to establish such an institution. The union believes that a sectoral parity-based fund would foster social convergence by improving social standards in the sector and could also help companies to weather cyclical downturns.

In summary, while operating mainly through 'soft tools' of information exchange, consultation and best practice transfer, international cooperation offers trade unions a mechanism for countering downward pressures on social standards through competition of local work forces at various levels. In addition, through best practice transfer international trade union cooperation can also encourage upward social convergence.

\subsection{Conclusion}

The results of our case study show that foreign-owned companies bring certain social standards to social dialogue, mainly by promoting works councils. At least on average they do not bring worse standards, the main reason being that host-country effects seem to prevail and foreign-owned companies mainly adapt to existing circumstances. This holds, of course, only for individual companies; a general dependence on foreign capital and the associated bidding wars could well erode the established standards of a host country. For instance, virtually all the new greenfield investments that the Slovene government proudly announced in 2017, most prominently the automobile parts maker Magna or robot manufacturer Yaskawa, received hefty investment incentives that could otherwise have been used to further social convergence through welfare state programmes ravaged in the aftermath of 2008 under the guise of austerity. The evidence collected suggests that, although offering mainly 'soft' tools, international trade union cooperation can be of great use in preserving existing standards across countries and can even bring about some positive social convergence by means of best practice transfer. Finally, by allowing workers to build coalitions across nations, it improves the participation of labour in democratic dialogue with decision-makers at supra-national level.

\section{CONCLUSIONS}

Since the outset of transition social dialogue in Slovenia has played a central role in both social and economic convergence, although the relationship between the two processes has changed with the transformation of industrial relations. In the early period, when the 'Slovene pattern' was constituted, labour's consent to measures crucial to economic restructuring was exchanged for institutional reforms enabling upward social convergence. A (proto-)exchange ensured that the privatisation process necessary for transition to a capitalist economy was carried out in a socially less disruptive form, with strong internal ownership, which also enabled a development path less dependent on foreign investment. Incomes policies that supported stabilisation, improved competitiveness and allowed corporate restructuring were exchanged for the institution of the minimum wage, modifications of the tax system and a favourable Labour Code, which reduced income inequalities and fostered social convergence. Throughout the 1990s, exchanges between 
partners in the peak-level tripartite ESC gradually built a relatively coherent economic model, mimicking Western coordinated market economies. The incomes policies that contributed to nominal convergence and a 'soft landing' in the euro zone by 2007 were also exchanged for elements of social solidarity.

After the main issues of the transition process were resolved by the mid-2000s, social dialogue was weakened, while organised labour had to defend the achieved level of social standards, notably against the attempted imposition of a flat tax. The weakening of consensus-building through dialogue also saw a gradual accumulation of macroeconomic risks, mainly in the form of foreign indebtedness. During the crisis the social dialogue collapsed, but the trade unions managed to prevent some reforms that threatened to increase inequality (such as mini-jobs). The collapse of social dialogue deepened the crisis, which brought many unilaterally imposed measures that negatively impacted social standards (austerity measures) but also adversely affected the conditions for future social convergence (for example, the fiscal rule, a costly 'bad bank' and restriction of democratic rights). In the period after 2013, social dialogue has been revived, producing some minor social reforms and performs a stabilising function, including sending signals of stability to international investors now that more importance is assigned to measures to attract FDI.

In summary, the contribution of industrial relations was strongest in the crucial period of early transition when the basic institutions of the Slovene economic model were erected; social and economic convergence were strongly intertwined in exchanges between the social partners. As economic and social convergence became decoupled the latter stalled, while the former proceeded by piling up risks, which then materialised with the crisis of 2008. The collapse of social dialogue adversely affected both social and economic convergence. The current revival of social dialogue (increase in collective bargaining coverage, bargaining on an ambitious new pact) indicates that the social partners still consider dialogue to be a lever for economic convergence with the potential for new exchanges leading to social convergence.

Developments in three important areas of social convergence in which industrial relations play a crucial role are observed closely in this chapter. In the area of income inequalities the passage from the period when economic convergence was negotiated against elements of social convergence to a period of erosion and subsequent collapse of dialogue is most clearly visible. Minimum wages and wage compression brought about by incomes policies kept income inequalities under control until the mid-2000s, while decentralisation of collective bargaining, followed by unilateral reforms such as regressive social assistance and austerity measures during the crisis brought a steady deterioration in this area. Trends in gender inequalities are better, but here too, trade union actions in defence of achieved social convergence (for example, strike agreement in the public sector) and the resilience of sectoral collective bargaining - which increasingly includes work-life balance issues - contributed to preserving the achieved level of social convergence. The adverse impact of the government's austerity measures, supported by EU authorities and employers, is still strongly felt. The health insurance system, however, offers an example of the continuing strong involvement of the social partners, whose direct influence on the risks covered and services offered has ensured encouraging results in terms of social convergence.

The case study examines the impact of multinational corporations in Slovenia on 
social dialogue and social standards at the company level, and studies international trade union cooperation in response to transnational employer activities. We find that foreignowned companies do bring some new social standards, for example, a more prominent role for works councils, but the established standards in the host country, including the power and stance of the trade unions, seem more important for establishing or even improving social standards in multinationals operating in Slovenia. Interestingly, despite operating mainly through 'soft tools' of information exchange, consultation and best practice transfer, we find that international trade union cooperation can make a notable contribution to social convergence by preserving and even advancing social standards.

\section{NOTES}

1. In the case of Slovenia, when discussing upward social convergence we must acknowledge that in many areas high social standards were achieved in the era of socialist self-management. However, in this chapter we discuss only the fortunes and misfortunes of upward convergence during the transition to capitalism.

2. For developments in social dialogue we rely mainly on Kavčič $(2004,2014)$.

3. Both the number of foreign companies and their share of employees in the respective sectors of these six unionists taken together are disproportionally high.

\section{REFERENCES}

Bembič, B. (2018), 'Changes in inequality outcomes alongside industrial relations transformation in Slovenia', in D. Vaughan-Whitehead (ed.), Reducing Inequalities in Europe: How Industrial Relations and Labour Policies Can Close the Gap, Cheltenham, UK and Northampton, MA, USA: Edward Elgar and Geneva: ILO, pp. 424-70.

Bembič, B. and H. Butković (2017), 'Segmentation on the labour market in Slovenia and Croatia: comparative assessment of experiences in the area of industrial relations', paper presented at the IREC conference, Warsaw, 7-8 September.

Bohle, D. (2009), 'Race to the bottom? Transnational companies and reinforced competition in the enlarged European Union', in B. Van Apeldoorn, J. Drahokoupil and L. Horn (eds), Neoliberal European Governance and Beyond: The Contradictions and Limits of a Political Project, Basingstoke: Palgrave Macmillan, pp. 163-86.

Böhm, L. (2011), O negativnih posledicah malega dela na ženske in brezposelne, flyer from the ZSSS press conference, Association of Free Trade Unions of Slovenia (ZSSS), Ljubljana.

Bole, V. (1997), 'Stabilization in Slovenia: from high inflation to excessive inflow of foreign capital', in M.I. Blejer. and M. Škreb (eds), Macroeconomic Stabilization in Transition Economies, Cambridge: Cambridge University Press, pp. 234-55.

Bole, V. (2002), 'Disinflation and labor market distortions: lessons from Slovenia', The wiiw Balkan Observatory Working Papers No. 020, January, Vienna.

Bole, V. and Mramor, F. (2006), “'Soft landing” in the ERM2: lessons from Slovenia', in J. Prašnikar (ed.), Competitiveness, Social Responsibility and Economic Growth, New York: Nova, pp. 97-117.

Breznik, M. (2018), 'Agencijski delavci', in M. Stanojević and S. Furlan (eds), (Ne)dostojno delo: prekarizacija standardnega in nestandarnega zaposlovanja v Sloveniji, Ljubljana: Fakulteta za družbene vede, pp. 160-79.

Buchen, C. (2007), 'Estonia and Slovenia as Antipodes', in D. Lane and M. Myant (eds), Varieties of Capitalism in Post-Communist Countries, Basingstoke: Palgrave Macmillan, pp. 74-5.

Crowley, S. and M. Stanojević (2011), 'Varieties of capitalism, power resources, and historical legacies: explaining the Slovenian exception', Politics and Society, 39 (2), 268-95.

Damijan, J.P. and Č. Kostevc (2017), 'Effects of FDI in EU new member states in the age of global 
value chains', in E. Gnan and R. Kronberger (eds), Schwerpunkt Außenwirtschaft 2016/2017. Direktinvestitionen: Trends, Erklärungsfaktoren, Barrieren, Vienna: Facultas, pp. 195-214.

Deželan, S. and M. Košak (2006), 'The development of the single European market for financial services and its effects on Slovenia', in J. Prašnikar (ed.), Competitiveness, Social Responsibility and Economic Growth, New York: Nova Science, pp. 119-36.

Djokić, D. (2015), 'Managerski odkupi podjetij in dobro korporacijsko upravljanje', in K. Kavčič, I. Rižnar and D.G. Omerzelj (eds), Iz raziskav v podjetniško prakso, Koper: Fakulteta za management, pp. 147-73.

Domadenik, P., J. Prašnikar and J. Svejnar (2000), 'Prestrukturiranje slovenskih podjetij v razmerah nepopolnih trgov', in J. Prašnikar (ed.), Internacionalizacija slovenskega podjetja, Ljubljana: Finance, pp. 59-82.

Domadenik, P., J. Prašnikar and J. Svejnar (2003), 'Defensive and strategic restructuring of firms during the transition to a market economy', William Davidson Working Paper No. 541, William Davidson Institute, University of Michigan, Ann Arbor, MI.

European Central Bank (ECB) (2012), 'Euro area cross-border financial flows', ECB Monthly Bulletin, February, 105-18.

Feldmann, M. (2007), 'The origins of varieties of capitalism: lessons from post-socialist transition in Estonia and Slovenia', in B. Hancké, M. Rhodes and M. Thatcher (eds), Beyond Varieties of Capitalism: Conflicts, Complementarities and Institutional Change in European Capitalism, Oxford: Oxford University Press, pp. 328-50.

Feldmann, M. (2014), 'Coalitions and corporatism: the Slovenian political economy and the crisis', Government and Opposition, 49 (1), 70-91.

Government of Republic of Slovenia (2015), Programme for Internationalisation 2015-2020, Ljubljana: Government of Republic of Slovenia.

Hall, P.A. and D. Soskice (2001), 'An Introduction to varieties of capitalism', in P.A. Hall and D. Soskice (eds), Varieties of Capitalism: The Institutional Foundations of Comparative Advantage, New York: Oxford University Press, pp. 1-68.

Hassel, A. (2014), 'The paradox of liberalization - understanding dualism and the recovery of the German political economy', British Journal of Industrial Relations, 52 (1), 57-81.

Humer, Ž. and M. Roksandić (2013), 'Protikrizni ukrepi in enakost spolov', research report. Ženski lobi, Ljubljana.

Javornik, J. (2016), 'Maternal employment in post-socialist countries: understanding the implications of childcare policies', in T. Roosalu and D. Hofäcker (eds), Rethinking Gender, Work and Care in a New Europe, Basingstoke: Palgrave Macmillan, pp. 189-213.

Kajzer, A., S. Jurančič, S. Kovačič, T. Kraigher and J. Šušteršič (2007), 'Plače, produktivnost in konkurenčnost', in L. Fajić, B. Vasle, A. Kajzer and M. Bednaš (eds), Ekonomski izzivi 2007, Ljubljana: Urad za makroekonomske raziskave in razvoj.

Kavčič, F. (2004), Ekonomsko-socialni svet 1994-2004, Ljubljana: Ekonomsko-socialni svet.

Kavčič, F. (2014), Ekonomsko-socialni svet 2004-2014, Ljubljana: Uradni list.

Kresal Šoltes, K. and B. Kresal (2016), Primerjava slovenskega in norveškega sistema: ukrepi za lažje usklajevanje dela in družine zaposlenih (primerjalna študija), Ljubljana: Inštitut za delo pri Pravni fakulteti v Ljubljani.

Laporšek, S. and P. Dolenc (2011), 'Prožna varnost v Evropski uniji in Sloveniji', Organizacija, 44 (2), 72-84.

Lavrač, V. and B. Majcen (2006), 'Economic issues of Slovenia's accession to the EU', Working Paper No. 31, Inštitut za ekonomska raziskovanja, Ljubljana.

Leskošek, V. (2012), 'Vpliv socialne države na (ne)odvisnost delavcev od tržnih pogojev zaposlovanja', Časopis za kritiko znanosti, 39 (247), 103-12.

Leskošek, V. and S. Dragoš (2015), 'Social inequality and poverty in Slovenia - policies and consequences', Družboslovne razprave, 30 (76), 39-53.

Marginson, P. and G. Meardi (2012), 'Big players, different rules? Multinationals and collective bargaining in Europe', Gusto WP6 Working Paper, University of Warwick, Warwick, Coventry.

Masten, I. (2010), 'Finančna stabilnost v Sloveniji in uravnotežen razvoj finančnega Sistema', in M. Simoneti (ed.), Razvojne priložnosti trga kapitala v Sloveniji po finančni krizi, Ljubljana: Inštitut za ekonomska raziskovanja, pp. 105-18. 
Meardi, G. (2012), 'Union immobility? Trade unions and the freedoms of movement in the enlarged EU', British Journal of Industrial Relations, 50 (1), 99-120.

Mencinger, J. (2003), 'Does foreign direct investment always enhance economic growth?', Kyklos, 56 (4), 491-508.

Mencinger, J. (2006), 'Privatization in Slovenia', Slovenian Law Review, 3 (1-2), 65-81.

Mrak, M. (2010), 'Plačilno-bilančni vidik neto prilivov kapitala v Republiko Slovenijo', in M. Simoneti (ed.), Razvojne priložnosti trga kapitala v Sloveniji po finančni krizi, Ljubljana: Inštitut za ekonomska raziskovanja, pp. 119-39.

Mramor, D. and B. Jašovič (2004), 'Capital market development', in M. Mrak, M. Rojec and C. Silva-Jáuregui (eds), Slovenia: From Yugoslavia to the European Union, Washington, DC: World Bank, pp. $280-81$.

Murn, A. (2017), 'Značilnosti ekonomskih neenakosti v Sloveniji', IB revija, 51 (1), 5-17.

Nölke, A. and A. Vliegenthart (2009), 'Enlarging the varieties of capitalism: the emergence of dependent market economies in East Central Europe', World Politics, 61 (4), 670-702.

Ost, D. (2000), 'Illusory corporatism in Eastern Europe: neoliberal tripartism and postcommunist class identities', Politics \& Society, 28 (4), 503-30.

Palier, B. and K. Thelen (2010), 'Institutionalizing dualism: complementarities and change in France and Germany', Politics and Society, 38 (1), 119-48.

Penner, A.M., A. Kanjuo-Mrčela, N. Bandelj and T. Petersen (2012), 'Neenakost po spolu v Sloveniji od 1993 do 2007: razlike v plačah v perspektivi ekonomske sociologije', Teorija in praksa, 49 (6), 854-77.

Poje, A., J. Vuga Beršnak and I. Štamfelj (2016), 'Dobre prakse usklajevanja dela in družine: primerjava slovenskega in norveškega Sistema', in M. Hrženjak (ed.), Spremembe očetovstva: moški med delom in starševstvom, Ljubljana: Mirovni inštitut, pp. 117-42.

Prašnikar, J., P. Domadenik and M. Koman (2015), Skrivnost državne lastnine v Sloveniji, Ljubljana: Ekonomska Fakulteta.

Prašnikar, J., J. Svejnar and P. Domadenik (2000), 'Enterprises in the post-privatization period: firm-level evidence for Slovenia', Eastern European Economics, 38 (5), 60-92.

Robnik, S. (2016), Enakost spolov - (̌̌e) nedokončana zgodba: pregled razvoja na področju enakosti spolov v Sloveniji, 1991-2016, Ljubljana: Ministrstvo za delo, družino, socialne zadeve in enake možnosti.

Senčur Peček, D. (2003), 'Novi zakon o delovnih razmerjih', Lex localis, 1 (1), 119-27.

Senjur, M. (2012), 'Slovenija, Evropska unija in evro v času finančne krize', paper presented at 6. Kongres računovodij, revizorjev, finančnikov in davčnikov, accessed 5 October 2013 at https:// marjansenjur.files.wordpress.com/2012/12/slovenska-evro-kriza-kongres-racunovodij.pdf.

Simoneti, M., A. Böhm, A. Gregorič, N. Cankar and Č. Borec, (2003), 'Sodelovanje zaposlenih $v$ lastništvu in delitvi dobičkov podjetij v državah EU in predlog rešitev za Slovenijo', povzetek poročila, Inštitut za primerjalno parvo, Ljubljana.

Stanojević, M. (2004), 'Production coalitions in Slovenian companies: employee participation in non-participative organizations?', Journal for East European Management Studies, 9 (3), $225-42$.

Stanojević, M. (2015), 'Sindikalne strategije v obdobju krize', Teorija in praksa, 52 (3), 394-416.

Stanojević, M. and A. Kanjuo-Mrčela (2016), 'Social dialogue during the economic crisis: the impact of industrial relations reforms on collective bargaining in the manufacturing sector in Slovenia', in A. Koukiadaki, I. Távora and M. Martínez Lucio (eds), Joint Regulation and Labour Market Policy in Europe During the Crisis, Brussels: ETUI, pp.441-97.

Stanojević, M. and A. Krašovec (2011), 'Slovenia: social pacts and political exchange', in S. Avdagić, M. Rhodes and J. Visser (eds), Social Pacts in Europe: Emergence, Evolution, and Institutionalization, Oxford: Oxford University Press, pp. 232-56.

Stanovnik, T. (2002), 'The political economy of pension reform in Slovenia', in E. Fultz (ed.), Pension Reform in Central and Eastern Europe, Budapest: ILO, pp. 19-73.

Stanovnik, T. and M. Verbič (2012), 'Porazdelitev plač in dohodkov zaposlenih v Sloveniji v obdobju 1991-2009', IB Revija, 46 (1), 57-70.

Thelen, K. (2012), 'Varieties of capitalism: trajectories of liberalization and the new politics of social solidarity', Annual Review of Political Science, 15, 137-59. 
Trobec, D. (2012), 'Influence of corporate environmentalism and indebtedness on operations of Slovenian companies', PhD thesis, Faculty of Economics, University of Ljubljana, Ljubljana.

Urad republike Slovenije za Makroekonomske analize in razvoj (UMAR) (1997), Pomladansko poročilo 1997, Ljubljana: UMAR.

Urad republike Slovenije za Makroekonomske analize in razvoj (UMAR) (2016), Poročilo o razvoju 2016, Ljubljana: Urad za makroekonomske raziskave in razvoj.

Urad republike Slovenije za Makroekonomske analize in razvoj (UMAR) (2017), Poročilo o razvoju 2017, Ljubljana: Urad za makroekonomske raziskave in razvoj.

Van Klaveren, M., K. Tijdens and D. Gregory (2013), Multinational Companies and Domestic Firms in Europe, Basingstoke: Palgrave Macmillan.

Vrhovec, P. (2010), 20 let Zveze svobodnih sindikatov Slovenije v sliki in besedi, Ljubljana: ZSSS.

Županov, J. (1985), Samoupravljanje i društvena moć, Zagreb: Globus. 